\title{
Biomarkers for the assessment of chlorpyrifos effects on earthworms and on soil functional parameters
}

\author{
Lucas Piola(1), Julio Fuchs ${ }^{(2)}$, María Luisa Oneto(1), Silvana Basack(1), Rosana Giménez(3), \\ Rubén Massaro ${ }^{(4)}$, Juan Carlos Papa ${ }^{(4)}$, Eva Kesten ${ }^{(1)}$ and Norma Casabé(2)
}

\begin{abstract}
(1)Universidad de Buenos Aires (UBA), Facultad de Ciencias Exactas y Naturales (FCEN), Departamento de Química Biológica (DQB), Toxicología y Química Legal, Ciudad Universitaria, Pabellón 2, 4 piso, 1428 Buenos Aires, Argentina. E-mail: Ipiola@qb.fcen.uba.ar, mloneto@qb.fcen.uba.ar, basack@qb.fcen.uba.ar, ekesten@qb.fcen.uba.ar (2)Consejo Nacional de Investigaciones Científicas y Técnicas, Toxicología y Química Legal, UBA, FCEN, DQB, Ciudad Universitaria, Pabellón 2, 4 piso, 1428 Buenos Aires, Argentina. E-mail: juliof@qb.fcen.uba.ar, nbcm@qb.fcen.uba.ar (3)UBA, Facultad de Agronomía, Area de Protección Vegetal, Avenida San Martín 4453, 1417 Buenos Aires, Argentina. E-mail: rgimenez@agro.uba.ar (4)Instituto Nacional de Tecnología Agropecuaria, Estación Experimental Agropecuaria Oliveros, Ruta 11, Km 353, 2206 Oliveros, Santa Fe, Argentina. E-mail: rmassaro@correo.inta.gov.ar, jcpapa@correo.inta.gov.ar
\end{abstract}

\begin{abstract}
The objective of this work was to evaluate the effects of chlorpyrifos on earthworms and on soil functional parameters. An integrated laboratory-field study was performed in a wheat field in Argentina, sprayed with chlorpyrifos at two recommended application rates $\left(240\right.$ or $960 \mathrm{~g} \mathrm{ha}^{-1}$ a.i. $)$. Laboratory tests included neutral red retention time, comet assay (single cell gel electrophoresis), and avoidance behavior, each using the earthworm Eisenia andrei exposed in soil collected 1 or 14 days after pesticide application, and the bait-lamina test. Field tests assessed organic matter breakdown using the litterbag and bait-lamina assays. Earthworm populations in the field were assessed using formalin application and hand-sorting. The neutral red retention time and comet assays were sensitive biomarkers to the effects of chlorpyrifos on the earthworm $E$. andrei; however, the earthworm avoidance test was not sufficiently robust to assess these effects. Feeding activity of soil biota, assessed by the bait lamina test, was significantly inhibited by chlorpyrifos after 97 days, but recovered by the $118^{\text {th }}$ day of the test. Litterbag test showed no significant differences in comparison to controls. Earthworm abundance in the field was too low to adequately test the sensitivity of this assessment endpoint.

Index terms: Eisenia andrei, agricultural soil, field assay, laboratory bioassay.

\section{Biomarcadores para a avaliação dos efeitos de clorpirifós em minhocas e em parâmetros funcionais do solo}

Resumo - O objetivo deste trabalho foi avaliar os efeitos do clorpirifós sobre as minhocas e sobre parâmetros funcionais do solo. Foi executado um estudo integrado campo-laboratório, em uma plantação de trigo na Argentina, onde foi aplicado clorpirifós em duas doses recomendadas (240 ou $960 \mathrm{~g} \mathrm{ha}^{-1}$ a.i.). Os ensaios laboratoriais incluíram tempo de retenção do vermelho-neutro, ensaio cometa (eletroforese em gel de célula única) e teste de fuga, cada um com a minhoca Eisenia andrei exposta aos solos coletados 1 e 14 dias após tratamentos, e teste com a lâmina-isca. Nos bioensaios de campo, avaliou-se a decomposição da matéria orgânica em sacolas com alfafa e com a lâmina-isca. As populações de minhocas foram avaliadas no campo com uso do método de extração com formalina e remoção manual. $\mathrm{O}$ tempo de retenção do vermelho-neutro e o ensaio cometa foram biomarcadores sensíveis aos efeitos do clorpirifós na minhoca $E$. andrei; porém, o comportamento de fuga não foi eficiente para avaliar tais efeitos. A atividade alimentar da biota do solo, avaliada pelo teste de lâmina-isca, foi significativamente inibida pelo clorpirifós após 97 dias, mas recuperou-se no $118^{\circ}$ dia do teste. O teste de sacolas com alfafa não mostrou diferenças significativas em comparação aos controles. A abundância das minhocas em campo foi muito baixa, para testar adequadamente a sensibilidade desta variável.

Termos para indexação: Eisenia andrei, solos agrícolas, testes de campo, bioensaios de laboratório.

\section{Introduction}

It is increasingly recognized that the protection of soils and their inherent communities must become a primary goal of environmental policy worldwide (Römbke et al., 2005; Filser et al., 2008).
Chlorpyrifos (O,O-diethyl-O-3,5,6-trichloro-2-pyridyl phosphorothioate), a broad spectrum systemic organophosphorus anticholinesterase insecticide, is widely used in Argentina in direct soil application for the control of agricultural pests. 
The toxicity of pesticides to soil organisms depends on the compound bioavailability, which is affected by the physicochemical properties of the compound and the soil, and by the uptake routes of exposed organisms. Therefore, ecotoxicity studies can benefit from using experimental designs that improve data relevance for local exposure conditions in the field (Yu et al., 2006; Filser et al., 2008). However, due to this complexity, assessment of the risks for soil organisms cannot rely exclusively on chemical analysis. In-vivo assays using sentinel species provide a more reliable assessment of toxicity because they are more representative of the natural soil conditions.

Earthworms are often used as terrestrial model organisms for ecotoxicity testing, because of their importance for the structure and function of soil ecosystems. Standard methods with the compost earthworms Eisenia fetida and E. andrei have been used in ecotoxicological research for decades (Organization for Economic Cooperation and Development, 1984). Biomarkers on sentinel organisms address the questions of bioavailability by only responding to the bioactive fraction. They have been used extensively to document and quantify both the exposure to and the effects of environmental pollutants, and have the potential to rapidly recognize effects that may affect populations and communities.

The types of biological responses that could be considered as biomarkers range from the molecular, subcellular and cellular to the effects on the intact organism, the population, or community structure, and perhaps also the structure and function of ecosystems (Colgan et al., 2003). Nonspecific suborganism biomarkers, such as lysosomal membrane stability measured as neutral red retention time, and DNA damage estimated by the comet assay are indicative of effects of more than one detrimental factor, and because of their sensitivity they may be relevant to assessing the risk of multiple chemicals (Xiao et al., 2006; Reinecke $\&$ Reinecke, 2007). In order to validate suborganism biomarkers, responses occurring at different levels of biological organization should be addressed (Colgan et al., 2003; Vasseur \& Cossu-Leguille, 2003).

Considerable attention has been given to the effects of agricultural practices on soil organisms, especially earthworms. The abundance and activity of earthworms in arable lands depends strongly on management practices; therefore, earthworms can act as potential bioindicators of land use practices (Suthar, 2009). Ecological tests, such as avoidance behaviour, based on the earthworm's ability to detect a toxicant and move away, may be sensitive and fast (Hund-Rinke et al., 2003). Ecotoxicological information gained from the earthworm studies can be supplemented by a more holistic (i.e., representative of multiple levels of ecosystem organization) endpoint, such as organic matter decomposition, which can be assessed in either laboratory or field studies (Knacker et al., 2003).

The objective of this work was to evaluate the effects of chlorpyrifos on earthworms and on soil functional parameters.

\section{Materials and Methods}

An integrated laboratory-field study, on a wheat field in Argentina, was performed. Wheat was machine-planted in a field in Santa Fe Province, Argentina $\left(33^{\circ} 55^{\prime} 24^{\prime \prime} \mathrm{S}, 61^{\circ} 16^{\prime} 42^{\prime \prime} \mathrm{W}\right)$, on a clay loam soil with an abundant residue cover. The mean annual rainfall and temperature are $726 \mathrm{~mm}$ and $16.5^{\circ} \mathrm{C}$, respectively. The experimental design consisted of randomized complete blocks with three replicates, each block comprising three plots of $13 \times 5 \mathrm{~m}$. The distance between blocks was at least $200 \mathrm{~m}$. At each block, randomly chosen plots were sprayed with commercial chlorpyrifos $240 \mathrm{~g} \mathrm{ha}^{-1}$ a.i. (low rate) or $960 \mathrm{~g} \mathrm{ha}^{-1}$ a.i. (high rate), 30 days after seeding, under controlled conditions, using a calibrated hand-pressure sprayer. Control plots were sprayed with water. The study was conducted in winter/spring (July 2005-November 2005).

For laboratory assays, soil samples from $0-10 \mathrm{~cm}$ depth were collected 1 and 14 days after treatments. Results of physicochemical analyses performed by the Geochronology and Isotopic Geology Institute (INGEIS), Buenos Aires, Argentina, were: $\mathrm{pH} 5.8$ 5.9; electrical conductivity $0.43-0.47 \mathrm{dS} \mathrm{m}^{-1}$; organic C 20.4-24.5 $\mathrm{g} \mathrm{kg}^{-1}$; organic $\mathrm{N} 1.65-1.81 \mathrm{~g} \mathrm{~kg}^{-1} ; \mathrm{C} / \mathrm{N}$ 12.2-13.5; Ca 8.3-9.0 cmol $_{\mathrm{c}} \mathrm{kg}^{-1} ; \mathrm{K} 1.6-1.8 \mathrm{cmol}_{\mathrm{c}} \mathrm{kg}^{-1}$; Mg 1.8-2.1 $\mathrm{cmol}_{\mathrm{c}} \mathrm{kg}^{-1}$; and P $10.0-20.3 \mathrm{mg} \mathrm{kg}^{-1}$. Soil samples for chlorpyrifos determinations were kept refrigerated until analyses, which were carried out by the National Agrifood and Quality Service (SENASA), Buenos Aires, Argentina, using gas chromatographic techniques.

Bioassays were performed using adult organisms of $E$. andrei, with a well developed clitellum, which were 
maintained in laboratory culture, by exposure to soil samples sieved $(\leq 2 \mathrm{~mm})$ and adjusted to $50-60 \%$ of the soil water holding capacity (WHC $=48.6 \pm 2.4 \%$ ). Unless other specifications, OECD/ISO guidelines were followed for the tests. To perform cellular/ subcellular assays, six adult earthworms were added to $300 \mathrm{~g}$ soil (three replicate containers per treatment). After a 7-day exposure, each earthworm was washed with water, dry blotted using a filter paper, and placed individually in a glass conical tube containing $1.5 \mathrm{~mL}$ of phosphate-buffered saline solution (PBS) $\left(\mathrm{Ca}^{++}\right.$, $\mathrm{Mg}^{2+}$ free). Worms were subjected to three short bouts of electric stimulation $(<1 \mathrm{~s})$ at $6 \mathrm{~V}$ DC. The coelomic fluid was immediately transferred to an Eppendorf tube. Viability was determined in an improved Neubauer hemocytometer, by diluting $10 \mu \mathrm{L}$ of cell suspension with $10 \mu \mathrm{L}$ of $0.4 \%$ trypan blue in PBS. The percentage viability was calculated based on the percentage of unstained cells.

The neutral red retention assay on the coelomocyte cells of each worm was measured according to Weeks \& Svendsen (1996) with slight modifications. Twenty microliters of coelomic fluid were placed on a microscope slide, and the cells were allowed to adhere for $60 \mathrm{~s}$, prior to the application of $20 \mu \mathrm{L}$ of neutral red working solution $\left(80 \mu \mathrm{g} \mathrm{mL}^{-1}\right)$ and a coverslip. Each slide was scanned for $2 \mathrm{~min}$, at 5-min intervals under a light microscope $(400 \mathrm{x})$. Observation went on until the ratio of cells with fully stained cytoplasm exceeded $50 \%$ of the total number of cells counted. This time was recorded as the neutral red retention time (NRRT).

The comet assay was performed on the same coelomic fluid (Casabé et al., 2007). We mixed $10 \mu \mathrm{L}$ of the coelomocyte suspension with $75 \mu \mathrm{L}$ of $0.75 \%$ low-melting-point agarose at $37^{\circ} \mathrm{C}$, and spread it over a microscope slide precoated with $100 \mu \mathrm{L} 1 \%$ normal-melting-point agarose. After $5 \mathrm{~min}$ of solidification at $4^{\circ} \mathrm{C}$, a second layer of low-melting-point agarose was placed on top and left to harden for $5 \mathrm{~min}$ at $4^{\circ} \mathrm{C}$. Slides were placed in alkaline lysis solution (2.5 $\mathrm{mol} \mathrm{L}^{-1} \mathrm{NaCl}, 100 \mathrm{mmol} \mathrm{L}^{-1} \mathrm{Na}_{2}$ EDTA, $10 \mathrm{mmol} \mathrm{L}^{-1}$ Tris, $1 \%$ N-lauryl sarcosinate, $10 \%$ DMSO, and $1 \%$ Triton X-100, $\mathrm{pH} 10$ ) and stored overnight at $4^{\circ} \mathrm{C}$. After lysis, slides were rinsed with neutralization buffer (0.4 mol L ${ }^{-1}$ Tris-HCl, $\mathrm{pH}$ 7.5) and immersed in freshly prepared alkaline electrophoresis solution (300 $\mathrm{mmol} \mathrm{L}^{-1} \mathrm{NaOH}$ and $1 \mathrm{mmol} \mathrm{L}^{-1} \mathrm{Na}_{2}$ EDTA) at $4^{\circ} \mathrm{C}$ for $12 \mathrm{~min}$, to allow DNA unwinding. Electrophoresis was conducted for 20 min at $25 \mathrm{~V}\left(1 \mathrm{~V} \mathrm{~cm}^{-1}\right)$ and a starting current of $250 \mathrm{~mA}$. One hundred cell nuclei per slide were rated visually and classified into four categories, according to the tail intensity (size and shape). The extent of DNA damage was measured as damage index (DI), a weighted value of damage according to cells distribution, defined as DI $=\sum$ (ni $\mathrm{xi}$ ), in which ni is the number of cells with damage class $i(0,1,2$ or 3$)$.

The avoidance behaviour was studied according to ISO 17512 (International Organization for Standardization, 2008) with slight modifications. Plastic, rectangular, two-chamber containers $(20 \times 10 \times 10 \mathrm{~cm})$ were used. Containers were divided into half with a plastic split, and $520 \mathrm{~g}$ of control soil were placed in one half of the container, and $520 \mathrm{~g}$ of treated soil was placed on the other side. After the split was removed, ten adult earthworms were placed on the centreline in the soil surface, and the containers were covered allowing sufficient aeration. After three days of incubation, the split was reintroduced, and the number of individuals in each compartment was counted. Four replicates were used for each test. For each block, a control dual test was performed with four replicates.

The laboratory bait-lamina test was performed as an adaptation of Helling et al. (1998). Containers were used with $350-400 \mathrm{~g}$ of soil, four bait-laminas and six earthworms, in each of the four replicates per treatment per block. The bait-lamina is a plastic strip perforated at 5-mm distances with 16 small (1-mm diameter) holes, filled with cellulose, wheat bran and activated carbon. After exposure for three days, the number of pierced holes in each lamina was counted.

Field assays to determine the effects of chlorpyrifos on organic matter decomposition included the litterbag test and the bait-lamina test. The litterbag test was performed according to Ingelsfield (1989) using bags filled with lucerne (Medicago sativa L.), with mesh size of either $0.2 \mathrm{~mm}$ (microflora, microfauna and mesofauna allowed), or $3.6 \mathrm{~mm}$ (microflora, meso- and macrofauna allowed). Litterbags were buried at $10 \mathrm{~cm}$ depth in the soil, before treatments with the pesticides (two replicates per treatment per block). Litterbags were sampled after 97 and 118 days. The contents were dried $\left(50^{\circ} \mathrm{C}, 48\right.$ hours) and weighed. Organic matter breakdown was calculated as the percentage of organic material mass loss at the sampling 
time $\mathrm{t}$ [(start weight-end weight) x 100/start weight]. Bait-lamina test was performed according to Von Törne (1990). Sixteen bait-lamina strips (as a 4x4 matrix) were inserted vertically into the top soil layer (three replicates per treatment per block). After 14, 97, and 118 days of exposure, laminas were removed from the soil and examined. The number of pierced holes in each lamina was counted.

To study natural earthworm populations, formalin $(0.2 \%)$ was used to extract them from the soil. Aclitellate and clitellate earthworms were counted and taxonomically identified.

Statistical analyses were performed with GraphPad InStat 3 (GraphPad Software, San Diego, USA). Data were first tested for normality (Kolmogorov-Smirnov's test) and for homogeneity of variances (Bartlett's test). Means were compared by one-way ANOVA (parametric) or nonparametric Kruskal-Wallis tests. Tukey-Kramer or the nonparametric Dunn's test was applied for post-hoc comparison of means. Linear correlations were performed using the Pearson linear correlation test. For avoidance experiments, pair-wise Student's $t$ test was used (one-tailed test for control-treated experiments; two-tailed test for dual control tests) (da Luz et al., 2004; International Organization for Standardization, 2008; Marques et al., 2009).

\section{Results and Discussion}

Soils treated with $240 \mathrm{~g} \mathrm{ha}^{-1}$ a.i. chlorpyrifos showed the same average concentration $\left(0.02 \pm 0.01 \mathrm{mg} \mathrm{kg}^{-1}\right)$ after 1 or 14 days of treatment application. In plots sprayed with $960 \mathrm{~g} \mathrm{ha}^{-1}$ a.i., concentration was $0.10 \pm 0.02 \mathrm{mg} \mathrm{kg}^{-1}$ after 1 day, and $0.03 \pm 0.01 \mathrm{mg} \mathrm{kg}^{-1}$ after 14 days from treatment application.

Chlorpyrifos was neither detected in soils sampled 97 days after treatment, nor in the control plots (detection limit: $0.01 \mathrm{mg} \mathrm{kg}^{-1}$ ). As chlorpyrifos soil concentration was similar for both treatments after 14 days, and due to the large number of soil samples to be processed, laboratory bioassays were only performed on samples of soils sprayed with the high rate of pesticide. Lysosomal neutral red retention time was significantly reduced in earthworms exposed for seven days to chlorpyrifos low-rate and high-rate treated soils, collected one day after spraying, when compared to controls (Figure 1). A significant concentration-response relationship was observed $(\mathrm{r}=0.888, \mathrm{p}<0.001)$. The reduction was also observed in earthworms exposed to soils sampled 14 days after treatment.

Neutral red retention assay has been used to assess concentration-response relationships for a variety of metals and organic compounds (Svendsen et al., 2004; Gastaldi et al., 2007). Few studies, however, showed effects on neutral red retention time in earthworms exposed to chlorpyrifos contaminated soils (Hodge et al., 2000; Casabé et al., 2007; Reinecke \& Reinecke, 2007). Our results showed that the neutral red retention time was sensitive to the low chlorpyrifos concentrations present in soil, and may constitute an early indication of impending physiological damage in the earthworms.

Chlorpyrifos produced a significant increase in damage index with respect to controls in coelomocytes of earthworms exposed to soils sampled one day after treatments (Figure 2). A significant increase was also observed on high-rate treated soils collected 14 days after spraying, although DNA migration was lower. In all experiments, the viability of cells was approximately 95\%. Damage to DNA, as measured with comet assay, may lead to mutations, strand breaks, altered bases and, finally, health disorders, resulting in severe disturbances in ecosystems which may lead, in some cases, to an elevated extinction risk of sensitive species.

Although comet assay is considered an important biomarker of DNA damage in earthworm ecotoxicology (Fourie et al., 2007), few studies have been reported on terrestrial environments (Martin et al., 2005; Xiao

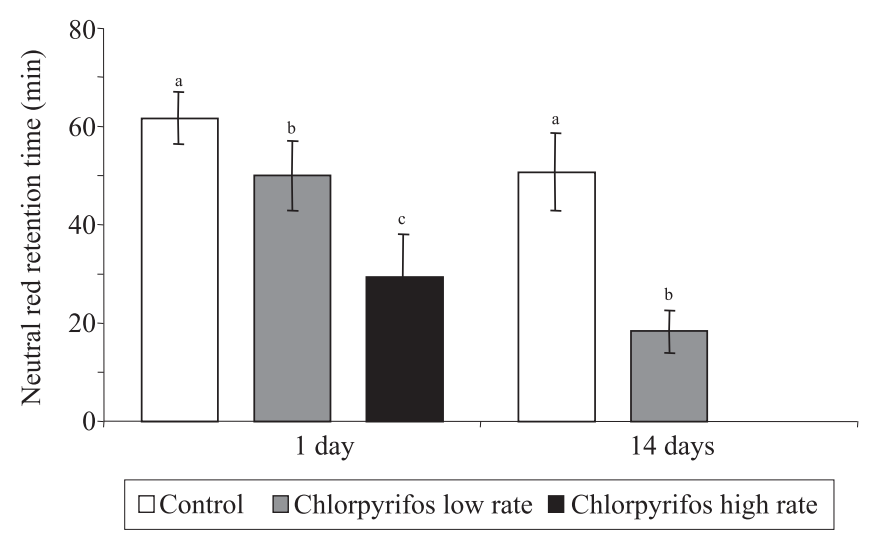

Figure 1. Neutral red retention time, in coelomocytes of Eisenia andrei exposed for seven days to control and chlorpyrifos-treated soils, sampled at different times after treatments. Mean \pm SD (three earthworms per treatment per block). Different letters denote significant differences between groups. 
et al., 2006). The comet assay applied on earthworm coelomocytes showed a high level of DNA damage, by exposure to chlorpyrifos treated soils. Neutral red retention and comet assays revealed alterations at subcellular level, and can be regarded as indicators to be used in the assessment of soil earthworms health. Previous results on a soybean field of the Santa Fe Province, sprayed with chlorpyrifos, showed a similar pattern in both cellular biomarkers (Casabé et al., 2007). In terms of the avoidance, earthworms exposed to soils sampled 14 days after treatment had varied results: when exposed to soils from block 1, earthworms preferred the treated substrate; in contrast, worms tended to avoid treated soils from blocks 2 and 3 (Figure 3). The responses were statistically significant. Soil physicochemical analysis showed no differences between blocks. No significant difference was found in the distribution of the worms between both chambers of the containers in dual control tests, which indicates an even distribution of individuals among the two sections of the test container.

Avoidance behaviour is an ecologically relevant endpoint, directly related to the energy budget of the worms, and indirectly to the soil structure. Exposure to pesticides that alters earthworm behaviour can induce migratory behaviour, which can lead to modifications in population abundance or biomass, and to changes in species diversity. Although avoidance tests with earthworms have been considered as suitable screening

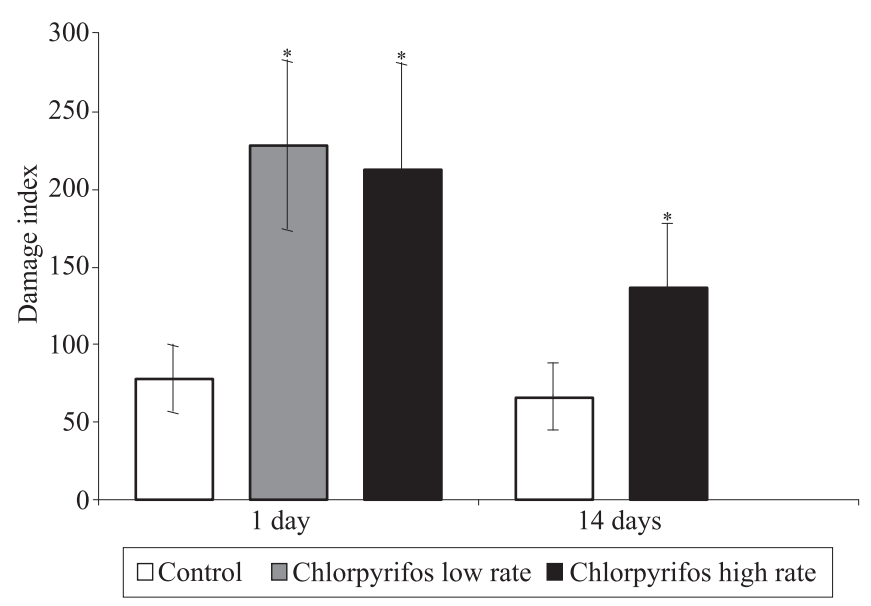

Figure 2. Effects on DNA migration of coelomocytes of E. andrei exposed to control and chlorpyrifos-treated soils, sampled at different times after treatments in the comet assay. Mean $\pm \mathrm{SD}$ (three earthworms per treatment per block). $*$ Significantly different from control, at $0.1 \%$ of probability. tools for the assessment of potentially contaminated soils (da Luz et al., 2004; Sousa et al., 2008), few studies were done with chlorpyrifos treated soils (Hodge et al., 2000; Zhou et al., 2007). The results of this study showed that the avoidance behaviour was not a sufficiently sensitive endpoint for assessment of the effects of chlorpyrifos on the earthworms.

Bait-lamina laboratory test showed a nonsignificant decrease in the bait consumption of earthworms exposed to treated soils collected 1 and 14 days after spraying, compared to controls (Figure 4). These results contrast with those reported previously for a soybean field on a clay silty soil sprayed with chlorpyrifos (Casabé et al., 2007). Physical structure and chemistry of the soils have a strong influence on this functional endpoint, and could account for the observed differences. In field experiments, feeding activity of soil macrofauna assessed with the field bait-lamina test increased with increasing exposure time (Figure 5). Fourteen days after introduction of the bait-laminas into soils, the substrate consumption rates, measured as the percentage of open holes in the bait-laminas, were very low, probably as a consequence of the low density of earthworms and of the short exposure time. No significant differences between treated and control soils were observed. Feeding activity was significantly decreased in both treatments, compared to control soils, after 97 days of exposure; however, no concentration-dependent relationship was observed. After 118 days exposure, a nonsignificant decrease was observed.

Chlorpyrifos treatment of the soil did not affect litter decomposition, after 97 or 118 days of the litterbag exposure in the field (Figure 6). The overall litter

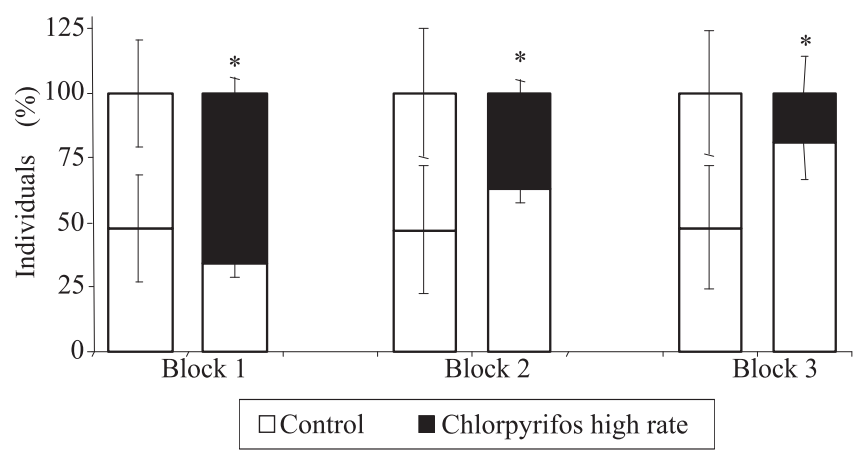

Figure 3. Distribution of Eisenia andrei on each section of the dual chamber test container, in the avoidance behavior assay. Mean \pm SD (four replicates per assay). *Significantly different from control, at $1 \%$ of probability. 


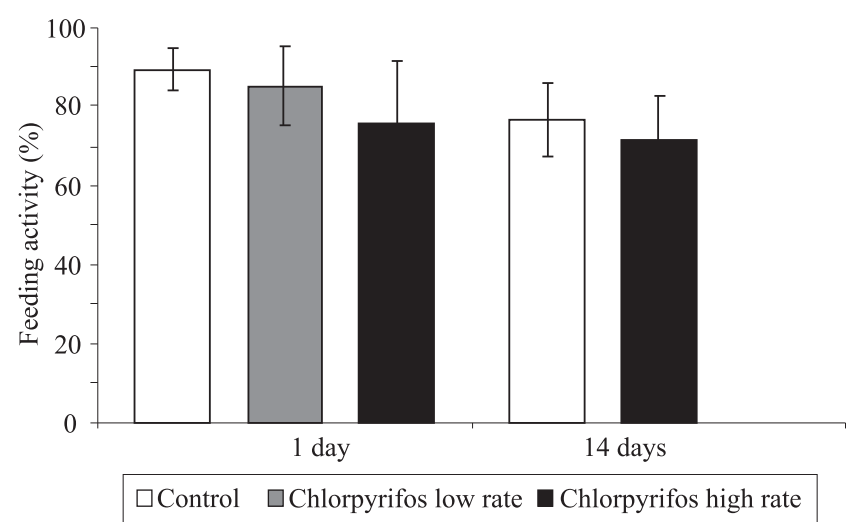

Figure 4. Feeding activity (three days) of Eisenia andrei in controls and chlorpyrifos-treated soils, sampled at different times after treatments in the bait-lamina laboratory assay. Mean \pm SD (four replicates per treatment per block).

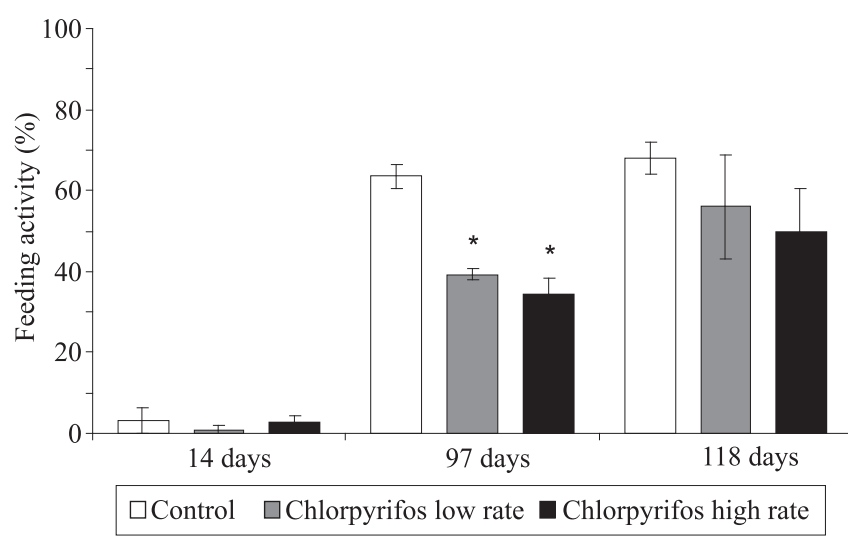

Figure 5. Feeding activity of soil fauna, in controls and chlorpyrifos-treated soils in the bait-lamina field assay. Mean \pm SD (three replicates per treatment per block). *Significantly different from control, at $0.1 \%$ of probability.

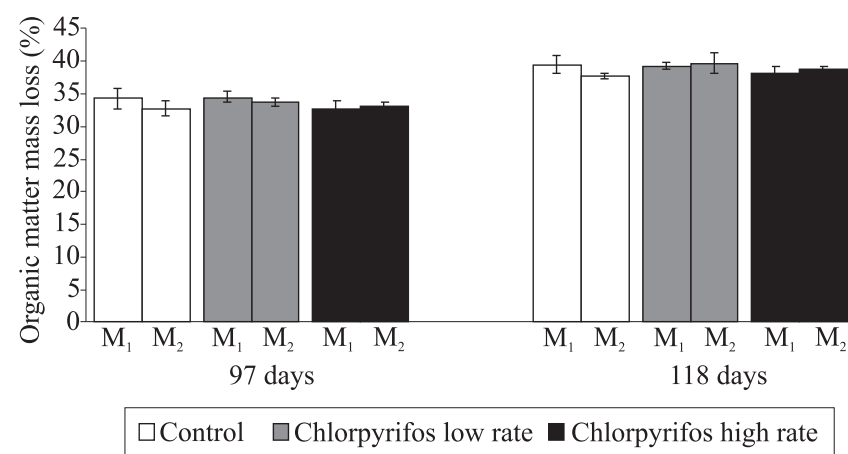

Figure 6. Organic matter mass loss in fine $(\mathrm{M} 1=0.2 \mathrm{~mm})$ and coarse $(\mathrm{M} 2=3.6 \mathrm{~mm})$ meshed bags, in the litterbag field assay. Mean $\pm \mathrm{SD}$ (two replicates per treatment per block). decomposition rate was very slow. No difference was detected between the decomposition rates of the leaves enclosed in the fine and coarse mesh litterbags.

Decomposition of organic matter is one of the most integrating processes in the soil ecosystems. Pesticides affecting this function might adversely influencenutrient cycling and soil fertility (Förster et al., 2004). The two assayed field methods showed a different pattern of response that could be attributed to the different quality and way of exposure of the organic matter used (Knacker et al., 2003).Besides, both functional endpoints are closely related to soil moisture content and abundance of earthworms in soil (Förster et al., 2004). The number of earthworms was very low in the first 14 days of the experiment - Octolasion cyaneum (Lumbricidae) and Microscolex dubius (Acanthodrilidae) ocurrences -, and no significant differences between control and treated soils were observed. No earthworms were found at the subsequent sampling dates.

\section{Conclusions}

1. The neutral red retention time and comet assays are sensitive biomarkers of chlorpyrifos effects, on the exposed earthworm Eisenia andrei.

2 . The earthworm avoidance test was not sufficiently robust for assessing the effects of chlorpyrifos on Eisenia andrei.

3. Feeding activity of soil biota, assessed by the bait-lamina test, is significantly inhibited by chlorpyrifos after 97 days, but recovers by the $118^{\text {th }}$ day of the test.

4. Chlorpyrifos treatment of the soil does not affect litter decomposition after the 118-day exposure of the litterbag in the field.

5. The earthworm abundance was too low to adequately test the sensitivity of this assessment endpoint.

\section{Acknowledgements}

To the University of Buenos Aires and to Consejo Nacional de Investigaciones Científicas y Técnicas, for the research grants.

\section{References}

CASABÉ, N.; PIOLA, L.; FUCHS, J.; ONETO, M.L.; PAMPARATO, L.; BASACK, S.; GIMÉNEZ, R.; MASSARO, R.; PAPA, J.; KESTEN, E. Ecotoxicological assessment of the effects of glyphosate and chlorpyrifos in an Argentine soya field. Journal of Soils and Sediments, v.7, p.232-239, 2007. 
COLGAN, A.; HANKARD, P.K.; SPURGEON, D.J.; SVENDSEN, C.; WADSWORTH, R.A.; WEEKS, J.M. Closing the loop: a spatial analysis to link observed environmental damage to predicted heavy metal emissions. Environmental Toxicology and Chemistry, v.22, p.970-976, 2003.

DA LUZ, T.N.; RIBEIRO, R.; SOUSA, J.P. Avoidance tests with collembola and earthworms as early screening tools for site-specific assessment of polluted soils. Environmental Toxicology and Chemistry, v.23, p.2188-2193, 2004.

FILSER, J.; KOEHLER, H.; RUF, A.; RÖMBKE, J.; PRINZING, A.; SCHAEFER, M. Ecological theory meets soil ecotoxicology: challenge and chance. Basic and Applied Ecology, v.9, p.346-355, 2008.

FÖRSTER, B.; VAN GESTEL, C.; KOOLHAAS, J.E.; NENTWIG, G.; RODRIGUES, J.M.L.; SOUSA, J.P.; JONES, S.E.; KNACKER, $\mathrm{T}$. Ring testing and field-validation of a terrestrial model ecosystem (TME) - an instrument for testing potentially harmful substances: effects of carbendazim on organic matter breakdown and soil fauna feeding activity. Ecotoxicology, v.13, p.129-141, 2004.

FOURIE, F.; REINECKE, S.A.; REINECKE, A.J. The determination of earthworm species sensitivity differences to cadmium genotoxicity using the comet assay. Ecotoxicology and Environmental Safety, v.67, p.361-368, 2007.

GASTALDI, L.; RANZATO, E.; CAPRÌ, F.; HANKARD, P.; PÉRÈS, G.; CANESI, L.; VIARENGO, A.; PONS, G. Application of a biomarker battery for the evaluation of the sublethal effects of pollutants in the earthworm Eisenia andrei. Comparative Biochemistry and Physiology Part C: Toxicology and Pharmacology, v.146, p.398-405, 2007.

HELLING, B.; PFEIFF, G.; LARINK, O. A comparison of feeding activity of collembolan and enchytraeid in laboratory studies using the bait-lamina test. Applied Soil Ecology, v.7, p.207-212, 1998.

HODGE, S.; WEBSTER, K.M.; BOOTH, L.; HEPPLETHWAITE, V.; O'HALLORAN, K. Non-avoidance of organophosphate insecticides by the earthworm Aporrectodea caliginosa (Lumbricidae). Soil Biology \& Biochemistry, v.32, p.425-428, 2000.

HUND-RINKE, K.; ACHAZI, R.K.; RÖMBKE J.; WARNECKE, D. Avoidance test with Eisenia fetida as indicator for the habitat function of soils: results of a laboratory comparison test. Journal of Soils and Sediments, v.3, p.7-12, 2003.

INGELSFIELD, C. Pyrethroids and terrestrial non-target organisms. Pesticide Science, v.27, p.387-428, 1989.

INTERNATIONAL ORGANIZATION FOR STANDARDIZATION. ISO 17512-1: soil quality - avoidance test for determining the quality of soils and effects of chemicals on behaviour - Part 1: test with earthworms (Eisenia fetida and Eisenia andrei). Geneve: ISO, 2008.

KNACKER, T.; FÖRSTER, B.; RÖMBKE, J.; FRAMPTON, G.K. Assessing the effects of plant protection products on organic matter breakdown in arable fields-litter decomposition test systems. Soil Biology \& Biochemistry, v.35, p.1269-1287, 2003.

MARQUES, C.; PEREIRA, R.; GONÇALVES, F. Using earthworm avoidance behaviour to assess the toxicity of formulated herbicides and their active ingredients on natural soils. Journal of Soils and Sediments, v.9, p.137-147, 2009.

MARTIN, F.L.; PIEARCE, T.G.; HEWER, A.; PHILLIPS, D.H.; SEMPLE, K.T. A biomarker model of sublethal genotoxicity (DNA single-strand breaks and adducts) using the sentinel organism Aporrectodea longa in spiked soil. Environmental Pollution, v.138, p.307-315, 2005.

ORGANIZATION FOR ECONOMIC COOPERATION AND DEVELOPMENT. Guideline for testing of chemicals, $n^{\circ} \mathbf{2 0 7}$ earthworms, acute toxicity test. Paris: OECD, 1984.

REINECKE, S.A.; REINECKE; A.J. Biomarker response and biomass change of earthworms exposed to chlorpyrifos in microcosms. Ecotoxicology and Environmental Safety, v.66, p.92-101, 2007.

RÖMBKE, J.; BREURE, A.M.; MULDER, C.; RUTGERS, M. Legislation and ecological quality assessment of soil: implementation of ecological indication systems in Europe. Ecotoxicology and Environmental Safety, v.62, p.201-210, 2005.

SOUSA, A.; PEREIRA, R.; ANTUNES, S.C.; CACHADA, A.; PEREIRA, E.; DUARTE, A.C.; GONÇALVES, F. Validation of avoidance assays for the screening assessment of soils under different anthropogenic disturbances. Ecotoxicology and Environmental Safety, v.71, p.661-670, 2008.

SUTHAR, S. Earthworm communities a bioindicator of arable land management practices: a case study in semiarid region of India. Ecological Indicators, v.9, p.588-594, 2009.

SVENDSEN, C.; SPURGEON, D.J.; HANKARD, P.K.; WEEKS, J.M. A review of lysosomal membrane stability measured by neutral red retention: is it a workable earthworm biomarker? Ecotoxicology and Environmental Safety, v.57, p.20-29, 2004.

VASSEUR, P.; COSSU-LEGUILLE, C. Biomarkers and community indices as complementary tools for environmental safety. Environment International, v.28, p.711-717, 2003.

VON TÖRNE, E. Assessing feeding activities of soil-living animals: bait-lamina tests. Pedobiologia, v.34, p.89-101, 1990.

WEEKS, J.M.; SVENDSEN, C. Neutral red retention by lysosomes from earthworm (Lumbricus rubellus) coelomocytes: a simple biomarker of exposure to soil copper. Environmental Toxicology and Chemistry, v.15, p.1801-1805, 1996.

XIAO, N.W.; SONG, Y.; GE, F.; LIU, X.H.; OU-YANG, Z.Y. Biomarkers responses of the earthworm Eisenia fetida to acetochlor exposure in OECD soil. Chemosphere, v.65, p.907-912, 2006.

YU, Y.L.; WU, X.M.; LI, S.N.; FANG, H.; ZHAN, H.Y.; YU, J.Q. An exploration of the relationship between adsorption and bioavailability of pesticides in soil to earthworm. Environmental Pollution, v.141, p.428-433, 2006.

ZHOU, S.; DUAN, C.; FU, H.; CHEN, Y.; WANG, X.; YU, Z. Toxicity assessment for chlorpyrifos-contaminated soil with three different earthworm test methods. Journal of Environmental Sciences, v.19, p.854-858, 2007.

$\overline{\text { Received on September 30, } 2008 \text { and accepted on July 6, } 2009}$ 